\title{
COLleCtive MeMORY AND NOMADISM: ETHNO-HISTORICAL INVESTIGATIONS IN BORNEO*
}

\author{
Bernard Sellato
}

Foreword: By the time this appears in print, it will have been ten years since this paper, one of my first, was written. To a certain extent, it now sounds clumsy. Some of the ideas put forth in it have since been much developed in subsequent publications. I feel now that a translation calls for some editing of the original text. Therefore, I have both introduced some slight changes into the text and recombined the original notes with added editorial notes. Table 1, which suffered from typos, was rectified. Jakarta, November 1990.

An 18-month (1979-1981) study among central Borneo ethnic groups was partly aimed at reconstructing these groups' histories, over a $20,000 \mathrm{sq}$. $\mathrm{km}$. region and as far back in time as possible. Some of these groups were nomadic hunter-gatherers in a more or less remote period of their history, but all are now practicing some degree of swidden rice agriculture. Different types of subsistence economy co-exist, however, with the dominant feature that they all resort to both cultivated paddy and wild sago, in varying proportions. Besides allowing for ethno-historical reconstructions, this investigation uncovered a clear connection between an ethnic group's collective memory and its social structure and, ultimately, its way of life, which ranges from complete nomadism to sedentary rice agriculture. ${ }^{1}$

\footnotetext{
"Translated by the author from: "Mémoire collective et nomadisme (Enquête ethno-historique à Bornéo)," Archipel 27 (1984): 85-108.

1 See Bernard Sellato, "Les nomades forestiers de Bornéo et la sédentarisation: essai d'histoire économique et sociale" (PhD dissertation, Paris, EHESS, 1986), pp. 54-56. I now consider that the connection is really of a different kind: it is ideology, determining both way of life and social organization, that conditions both the need for, and the practice of, maintaining and preserving historical tradition, thus the capacity for collective memory. In the case of the nomads, ethnic identity is supported by an ideological identity, which expresses itself in a way of life (see Sellato, Nomades et sédentarisation à Bornéo-Histoire économique et sociale (Paris: Editions de l'EHESS [Etudes Insulindiennes/Archipel no. 9], 1989), pp. 248-50; and idem., "The Punan Question and the Reconstruction of Borneo's Culture History," in Change and Development in Borneo, ed. V. H. Sutlive, Jr., forthcoming). Note that throughout this paper, the term "nomadism" refers particularly to "tropical rainforest nomadism" while "sedentary agriculture," in contrast, stands for what is currently called "semi-nomadic swidden cultivation."
} 
Oral tradition plays a foremost part in the functioning of these societies. It touches on every aspect of daily life, regulates the individual's behavior under every circumstance, allowing for a very low degree of autonomy within the group, whose identity, coherence, survival, and expansion it guarantees. Historical tradition, upon which this study is based, is not conceived of as distinct from the other segments of oral tradition.

\section{The Historical Data In Bornean Oral Tradition}

\section{Its Sources}

Where do we find historical data? First, by asking the elders: this is the simplest and chief source of information. It is also the most prone to alterations, as will be described later. Contrary to folktales, which almost never yield historical data positioned in time and space, the epics are valuable sources, as it is well-known that their being sung is a very positive feature for their preservation (mnemonics based on rhythm, verse length, rhyme), and some are obviously very old. One often observes elders looking to an epic for a historical fact when their memory fails them: "The epic goes like this ..."

A difficulty is that the language of the epics is replete with archaic terms, loanwords, and metaphors, making it somewhat esoteric. In socially stratified societies, only in the aristocratic families were the keys to this language transmitted from one generation to the next, and today only elderly aristocrats still master, although not always totally, this grand and beautiful poetic tongue. Sections of the epics have now become (definitively?) inaccessible to us, and the singers no longer know anything of the story they tell except for what the epic itself says, if even they can still comprehend it. Historical data are sometimes found in narrative tales, most often with distinctive mythical traits-like some allusion to an ancient settlement, a landmark near which the group lived in forgotten times-that the narrator recites without knowing anything of the historical episode they refer to.

\section{The Constituent Elements of Historical Data}

An event of the past can be roughly defined by the knowledge we have, through a given text, ${ }^{2}$ of a certain number of elements: the plot of the story, its scenario; the main characters it puts into action and their names; its localization in space and time; its setting and the causal relationship between units of action; some minor elements concerning secondary characters or details of the action; finally, an assessment of the historical objectivity of the narrative. The minimal account we can have of an event is an outline of its scenario: "Someone did this." Past events can only be partially captured, as accounts rarely submit their "complete" form, that is, all the elements above, to the investigator.

Besides, whatever historical information a text might contain can be found disconnected from its historical context, because the historical narrative has been diluted in a later, superimposed literary formulation and has been transmuted into a legend or a myth. Then, the investigator faces the task of reconstituting in the best possible way-by cross-checking with other texts-the event referred to, its plot, its protagonists and their deeds, and its position in space and time.

\footnotetext{
2 Throughout this paper, I call "text" any recorded or transcribed document, originating from an informal interview or representing a piece of formal or informal oral literature.
} 


\section{The Forms of the Historical Data}

A piece of information with historical value, that is, referring to an event of the past, has been recorded in the group's collective memory. The form in which it was immediately recorded is that of a historical narrative. If it survived, this narrative might have evolved through time into a historical-legendary narrative, a kind of saga or chanson de geste in which, progressively, the original elements were altered and supernatural elements introduced. In a later stage, the narrative might have acquired a mythical dimension, where an intermingling of the human and supernatural worlds was consummated. I am not referring here to a myth, strictly speaking, but to a narrative with mythical traits, or mythical narrative.

How do the historical data appear to the investigator in these crudely categorized forms of texts? A historical narrative refers to a relatively recent event that the informant has learned about first-hand, for example, an expedition in which his grandfather participated. ${ }^{3}$ The scenario of such a narrative is rich in details; names of characters, even secondary ones, are remembered; the space and time setting of the action is precisely determined; the deeds and their causes and consequences are indicated; style is realistic; and eventual stylistic additions by the informant do not much alter the reliability of the account.

The historical event to which the legend refers is already ancient, and several generations of narrators have kneaded the original narrative, embroidering on it, emphasizing certain sections, shading off others sometimes till they totally fade away, adding in supernatural and magical elements. Historical objectivity disappears, ascription of deeds to characters becomes chancy, certain sections are totally implausible. Place and time assignation, however, remains generally possible, and the outline of the scenario can be reconstructed through an interpretation of intertextual and other elements.

What remains, in the mythical narrative, of the historical data after innumerable manipulations? What we know of the historical event we suspect shows through the myth is most often restricted to the basic plot, and yet we have to transcribe it after having stripped it of its mythical attributes. We then find that we most likely face a real historical event, but that it has been disjointed from its context and is now drifting in time. Its geographic location is often hazy, some "region of origin" of the group, not always the true one. ${ }^{4}$ Sometimes, because of an outstanding landmark referred to in the narrative, the location is very precisely ascribed, but nothing allows a determination of the time, as the narrative clearly refers to a period beyond the oldest historical memories. The characters are often unknown, sometimes they are archetypal ones and, though their names might have reached us, their ethnic affiliation may remain uncertain. These characters are often alluded to as being "spirits" or, sometimes, mythical animals. 5

Then, historical data can be found at every stage in the evolution of the account of a historical event, as it can persist, though in a minimal form, through time and through the adulteration of the original narrative. At the stage of the mythical narrative, it might represent only a particle of history suspended in time, no longer connected to anything known, and all we can say is that it is very ancient.

\footnotetext{
3 This also includes narratives of events which the informant himself witnessed or took part in, usually called "personal history" or "personal narrative."

4 More, perhaps, than other constituent elements of narratives, the "region of origin" is the focus of idealized, or rather ideologized, constructions and manipulations (on the Busang and Kayan, see Sellato, "Les nomades forestiers de Bornéo," pp. 301-307, 417).

5 See Bernard Sellato, "Le mythe du Tigre au centre de Bornéo," ASEMI 14, 1-2 (1983).
} 


\section{The Ethno-Historical Reconstruction}

The main step in ethno-historical reconstruction is to determine, from pieces of historical information originating in many different texts and sources, the relative chronology of events, and to arrange them in a sequence. Sometimes the informant spontaneously provides such a sequence, positioning the event under scrutiny in chronological relation to other events. Most often, however, this has to be done by the investigator, who confronts various sets of data bearing a chronological value (genealogies, sequence of settlements) and validates a relative chronology of salient historical events for a given community or ethnic group. Historical interaction of two communities (wars, alliances) allows, through the crosschecking of their respective chronologies, for a more reliable time frame.

Absolute chronological approximations can be secured through a computing of genealogies and, sometimes, settlement shifts, insofar as precise data on the reasons of these shifts ${ }^{6}$ is available. Absolute datings are also provided by certain events of regional reach, that are documented in written sources, such as the Krakatau volcanic explosion, the Sarawak Iban wars, or the colonial interferences.

The investigator also attempts to reconstruct the event's scenario, its causes and consequences, and its major phases, by cross-checking several mutually illuminating texts. It is important, in order to ponder the subjectivity of the opinion the members of a given community have of an episode of their own history, to investigate also among the neighboring communities that were that community's protagonists in that episode. A fair knowledge of all these groups' customs allows the investigator to deduct, by comparison of two prejudiced accounts, the event's most plausible scenario.

More generally, a critical comparative analysis of the various versions offered by informants concerning the same event is necessary, and the investigator can establish his own version, the objectively most plausible of all. Indeed, by the end of his work, the investigator has at his disposal more data on that event than any individual informant. ${ }^{7}$ To the reductionist approach, taking as historical tradition the minimal version generally agreed upon by the whole set of informants, I am tempted to oppose a maximalist approach: Historical tradition would be represented by the most plausible broadest, "maximal" version, such as the investigator has established it, taking into account the data he has at his disposal, plus his insider's intuitive knowledge of the customs and mode of rationalization of the ethnic groups he studies, which allows him to deconstruct alterations of the narrative using a contrario the same specific local patterns that determined the alterations.

This does not mean that this "maximal" version is to be seen as definitively validated, and the use of the conditional is recommended. However, it should be recognized that the "maximal" version likely is the closest representation we can get of the real historical event. Contrary to the minimal version, it allows for fertile speculations. ${ }^{8}$

\footnotetext{
6 It should be first established whether a given settlement referred to in a narrative was a long-term hardwood longhouse or a light temporary settlement. The latter usually lasts three to ten years, whereas the former would last two or three decades. Besides the periodical need to move the village closer to fresh swidden land, other common causes for settlement shift are practical ones (wars or epidemics) or supernatural (curses or omens).

7 Indeed, through inspection of other communities' oral tradition and whatever written sources are available, he often has more data at his disposal than the sum of all the community's knowledgeable individuals.

8 Contrary to the minimal version - a mere skeleton of successive facts with little juncture-the maximal version gives flesh and blood to the account and also provides a better understanding of the causal relationships between the facts. In short, it makes more sense, it gives sense to history (see a discussion in Sellato, "Les nomades forestiers de Bornéo," pp. 29-56).
} 


\section{Ethno-Historical Analysis of Texts}

We have described three formal categories of texts in which historical data can be found. This data can either be apprehended directly, or needs to be observed through a screen and processed, or again cannot be used at all.

\section{Three Texts}

Here below are three texts, such as they were told by the elders, rendered in translation with as little change as was possible. Between brackets, I provided comments that I deemed necessary to the general understanding of the texts. For names of rivers and settlements, the reader is referred to maps in other publications. ${ }^{9}$

The first text is an Aoheng historical narrative, describing an attack by the Iban of Sarawak against the Long-Apari subgroup of the Aoheng (or Penihing) of the Upper Mahakam River around 1915. The second text is a sort of saga, a blend of history and legend, told by the Hovorit subgroup of the Hovongan (or Punan Bungan) of the Upper Kapuas River to account for a destructive expedition by the Taman against them around 1835. The third text, displaying clear mythical traits, provides an account by the Upper Kasau subgroup of the Seputan (Upper Mahakam) of their initiation to the major purification ritual; the historical event alluded to is ascribed to a period before or around 1750 .

\section{Text 1 : The Iban Expedition to Noha Maci'}

After the Great Iban War [1885] against the peoples of the Upper Mahakam, our community lived scattered for several years. Then, we gathered again at Long Okap, far downstream from our village of Long Apaé [burnt to the ground by the Iban, like all other Aoheng villages]. We lived there a long time. Part of us went back upstream to settle at Monyu'i, not far from Long Apaé. There we caught some Iban who had come to steal [to collect] resins on our territory and we took their heads. For fear of reprisals, we moved again downstream, somewhat scattered, staying one year at Long Kasau, one year at Nango Mari, then three years at Noha Boan Ori.

We were not welcomed by the other Aoheng, who were making us responsible for having triggered the Great lban War [they certainly were right] and feared that these new heads we had just taken would cause another massive Iban expedition. Bang Lawing, the chief of the Kayan of Long Belu'u, and Lijiu Li' Iprobably the grand-son of Lijiu Li' the Great, the "Dayak Napoléon"], the chief of the Busang of Long Pahangai, wanted to prevent us from going back to our traditional territory, near the Sarawak border [the Kayan and Busang were the largest regional groups and the Aoheng's de facto suzerains, in charge of regional politics and security]. They forced us to settle at Noha Silat, a short way downstream from the confluence of the Kasau (or Kacui) River.

There we remained a long time. But our king, Tingang Kuhi, was not happy to have to take orders. He had to yield, though, since he deemed it necessary to ensure the Kayan's and Busang's protection. After several years, however, he moved upstream with a part of our community, settling at Penyevahan, while the rest of us, under old Mira', chose to remain at Noha Silat.

\footnotetext{
${ }^{9}$ See Bernard Sellato, "The Upper Mahakam Area," Borneo Research Bulletin 12,2 (1980): 40-46; idem, "Les nomades forestiers de Bornéo"; idem, Nomades et sédentarisation a Bornéo.
} 
At that time, a group of warriors from Long Cihan [the Cihan subgroup of the Aoheng, some distance downstream] went to Litu [the Barito River headwaters] and took four heads. When they returned, the [Dutch] administration learnt about their deed and caught them, but one of them, Savang Turi', escaped to Penyevahan. The Dutch wanted to prevent us from taking heads and to take our children away to school [the first missionary school opened at Laham, far downstream, in 1915]. We were afraid of school. Tingang Kuhi was taken to the military outstation of Long Belu'u for having hidden Savang Turi', but he ran away and walked upstream along the Mahakam to Long Cihan. From there he was taken by canoe up to Noha Silat, and walked again to Penyevahan.

He was very upset with the [political] situation on the Upper Mahakam and, following his wife Dirung's advice [she was the daughter of the chief of the Huvung subgroup of the Aoheng], he decided to take his people across to Sarawak. First, he moved his settlement to Noha Maci', near the sources of the Mahakam [the starting point of the track across the mountains], then he went himself with a few men to Sarawak to request the [Brooke] Raja's permission to settle there. At the start of the track toward Sarawak, he met with a party of Iban building canoes. They pretended they were going to the upper Meraseh River [on Busang territory] to collect resins. Actually, they were preparing to attack the Aoheng but Tingang, unaware of the fact, went on on his way toward Sarawak.

Shortly afterwards, these Iban sent a messenger to Noha Maci', summoning the Aoheng leaders to their camp. Savang Kulau and a party of Aoheng warriors went up the Mahakam and bumped into the Iban on their way down. All of Savang Kulau's party, eight men, were killed. Among them, Nyangun, Lasah, brave warriors. The Iban casualties amounted to a canoe crew, three men. The Iban went on down the river to Noha Maci' which they attacked en masse, killing many people, including Tingang's wife, Dirung, three of his children, and two slaves. Then they returned home, leaving some of their men on the battlefield, including their chief Akeng, killed by Moring.

The Aoheng survivors fled to join their kin in Noha Silat. As for Tingang Kuhi, he remained a long time in Sarawak, where he learnt about the slaughter of his people, then he went to Pontianak and up the Kapuas River, crossed the [Müller Range] mountains via the Bungan and Huvung Rivers, and reached Noha Silat. There he remained many years, before finally [when the Pax Neerlandica was achieved] moving all his people back again to their traditional territory, settling at Long Apari [1935; they are still there today].

\section{Text 2 : The Tüari War}

Lavang Daru' [Lavang the Long, the Tall] and Lavang Cari are two brothers, chiefs of the village of Diang Bovo' [diang, limestone peg or cliff]. Their younger sister, whose name I forgot, has just died and her funeral is being prepared. Lavang Daru' leaves for downstream, carrying a large jar [the funerary jar in which the deceased's bones will be gathered after the body has been left to weather; meanwhile, a fresh human head must be secured; the jar is then stored in a cave]. He moors at a Tüari [the name the Hovongan use to refer to the Taman and Maloh] village and tries the jar on the head of a chief's daughter [an aristocratic head is more highly valued], but the child's head is too big. So he goes, from one Tüari village to the next, trying his jar on the heads of all chiefs' daughters. Nobody dares oppose him, as he is very tall and very strong. Finally, in an Embalo village [the Taman or Maloh of the Embaloh River], he finds a chief's daughter whose head fits exactly the mouth of his jar. He cuts it and returns to Diang Bovo'. Now the deceased's dried bones are ready. They are placed in the jar, and the girl's head becomes its stopper. 
All the Tüari of the Kapuas basin now get together to kill Lavang Daru'. They go up the river and gather on the flat of Data Halo' [the cassava flat], at the foot of Diang Bovo' buttress. Lavang Daru' comes down to offer rice to the assailants and says: "Tomorrow we shall fight; today you shall build huts, eat, and rest." The next day, Lavang Daru' comes down in full war attire, attacks the Tüari and kills them all. He spares some, however, whom he urges to come back with a larger army of stronger warriors. The Tüari survivors are halted on their way back home by the neighboring Hovongan people of chief Tesoing Loing [the one who can fly] who, by order of Lavang Daru', cut a hand off one, an ear off another, and punctured an eye of a third.

Shortly afterwards the Tüarï return, more numerous, to attack Diang Bovo', but suffer the same defeat. Lavang Daru' again spares three men, whom he entrusts with the following message: "I wish to die now, since my little sister is dead; if you want to kill me, you ought to forge war swords one fathom long, because I am very tall; only then will you be able to kill me." To his younger brother Lavang Carï he says: "I want to die but you, you must live for our progeny."

The Tüari forge fathom-long war swords, one for each warrior, and return again to Data Halo', thousands of them. Lavang Daru' first kills his wife and his children, to the last. Then he comes down to fight. He kills half of the Tüari, but then his two feet are chopped off, he goes on fighting, but then his two knees are chopped off, he is still fighting, but then his two thighs are chopped off, and he still fights. Finally, his right arm is chopped off, and he collapses. Only one third of the assailants remain alive. Lavang Cari has time to chop his brother's head off and take it to a safe place [to give it a funeral], so that the Tüari do not have it.

The Tüari go back home, without taking the chance to attack the other Hovongan village, because chief Tesoing Loing and his fellow Bang Kahavong [the one who splits (his enemy) in two] are even stronger than Lavang Daru' was. The latter and all his family were laid to rest by his brother in caves at Diang Lavang Daru' [Lavang Daru's caves], near Data Halo'. The Tüarï never came again.

\section{Text 3 : The Gong of Long Nekerahé}

The first ones of our group [the Upper Kasau subgroup of the Seputan] who were real human beings were Otü Tarin and Otü Koeng [a woman and a man]. They are called ot $\ddot{u}$ [spirits] because they were born of spirits, but they were human beings. Their forebears were Tingang Takin Bala [a male spirit] and Uhing Tuban Baja' [a female spirit]. These were brother and sister and, at the same time, husband and wife. After their union was consummated, Uhing fell ill and could not recover, her face was livid [the regular symptoms after the transgression of a taboo]. All sorts of four-legged animals were sacrificed, in vain.

One night, an old man of the village had a dream in which a tiger, coming from Orong Hivan [literally, the lower region of Iban country], appeared to him and told him: 'Uhing won't get well again if you do not shift your village." Upon waking up, the old man spread the news, and the people started dismantling the village. The tiger appeared again to the old man, saying: "The chief's house should be built first." Then, the villagers went to the confluence of the Nekerahé River [an upper tributary of the Kasau] and dug a hole in the ground for the principal pile of the chief's house. At a depth of about a half fathom, they found a gong and, after they dug it up, they found two pigs [the domestic pig, as opposed to the wild boar]. It was the first time humans had ever seen this animal. The pigs were 
raised with much care. Then a little blood, taken from one of the pigs' ears, was used to anoint Uhing. She progressively recovered.

Then the tiger appeared again and said: "See what I have taught you; from now on, you shall be able to make your life better." It was at this time that our people first carried out the great ritual of mengosang, with the blood from one of these pigs' offspring that was sacrificed to purify the whole village. This ritual of mengosang, we still carry out nowadays, in the same way, should circumstances require it [after an epidemics, a serious breach of taboo, or several poor crops in a row].

\section{Analysis of the Elements of the Texts}

\section{Text 1 : A Historical Narrative}

The event itself is precisely positioned in its historical context and the text provides a number of details on the protagonists, their names, their kinship relations, and the action's successive settings and successive phases, even minor ones (like Tingang's return). The text shows a concern for objectivity: It recognizes that the Aoheng suffered a major setback, that their provocations were the cause for the Iban expedition, that the Aoheng were under a protectorate imposed by the larger ethnic groups of the Upper Mahakam. Therefore it is a historical text in the full sense of the word, objective and without self-flattery.

\section{Text 2 : How to Transform a Defeat into a Victory}

Besides the loss of certain names (Lavang's sister, the Tüari chiefs), this text displays complacent alterations to the original historical narrative, which became "the Saga of Lavang Daru'." A number of transpositions and interpretations occurred that we can try to deconstruct and interpret in the opposite way. For instance, Lavang's ostentatious and provocative quest for a head certainly stands for a less-than-glorious ambush against an isolated child (and maybe not a chief's daughter). In the triplicated episode of the Tüari expedition, the first two failed attempts only serve to introduce in the narrative the undeniable final victory of the Tüari, a very numerous ethnic group. The hero's desire to die and his murdering his whole family only serve to conceal another historical fact that could not be evaded, that Lavang and his family were killed by the Tüari, who came specially for him. The Hovongan found some consolation in the fact that Lavang's head could be made away with by his brother. The Tüari did not dare attack the other village, because "Tesoing Loing is even stronger." This avoidance probably conceals the other Hovongan subgroup's escape to the forest or to caves and their abandonment of their village.

The whole episode can then be reconstructed as follows: For the funeral of his sister, the hero went to "steal" a head (this corresponds to a local expression, meaning to ambush an isolated individual, preferably a woman or child, and run away with the head), and a Tüari expedition (maybe just a small party was enough) wiped out the Hovorit subgroup of the Hovongan, in spite of the hero's bravery. The end of the narrative is particularly revealing: The Tüari, the text concludes, "never came again," which implies to the audience: "They've learned the lesson we taught them." The lesson, really, is that the Hovongan have refrained ever since from ambushing the Tüari to take their heads (they subsequently took heads among the neighboring Mandai group).

\section{Text 3 : Two Great Mythical Themes}

Two important myths of the Seputan and Aoheng are found here. The myth of the original incest is not specifically a Seputan theme, nor even a Dayak one. Incest, conceived of as 
a compulsory practice when it concerns either the first human couple or, as is probably the case here, the only two aristocratic (spirit) individuals, entails disease, typically a slow decline. ${ }^{10}$ This can be cured only through the performance of the major purification ritual which, somehow, evacuates the incest and allows the real human beings to be descended from the spirits.

In Aoheng myths, the initiating or "civilizing" hero is always the tiger or a character by the name of Tiger, ${ }^{11}$ coming from elsewhere (commonly downstream). He acquaints the "still stupid" humans with the rites (adet) and introduces new cultural elements and techniques. Here he is responsible for the discovery of the domestic pig and the ritual practiced with its blood.

What historical data do we find? The couple are really spirits, precursors of mankind. Their genealogy is hazy and cannot be linked to chiefly genealogies, known from around 1800 , but they are considered the forebears of the whole Seputan subgroup. Except for them, no personal name is recalled in the narrative, not even the old man's. The episode is situated at Long Nekerahé, for this is the oldest settlement (around 1800) of which the Seputan have a remembrance. We know, however, that these Seputan lived earlier on the Busang River (a tributary of the Barito). This initiation to the major ritual must really have occurred before the period of their residence at Long Nekerahé.

We can, then, consider this text as a myth. Its geographic localization is chancy, the characters of the mythical forebears cannot be connected to the genealogies, and the dating is impossible. There is precious little in this text that might be of any use in a historical reconstruction. ${ }^{12}$

\section{Erosion of a Text's Historical Contents}

The study of the three texts above shows that the historical contents of a historical narrative erode progressively through time. The episode referred to in the first text dates back to 1915; in the second, to about 1835; and in the third, to around 1750. Observation bearing on dozens of such texts leads us to recognize that the various constituent elements of a text show a differential resistance to erosion. These elements were enumerated earlier, in decreasing order of resistance. It is the minimal plot of action that resists best, even through alterations (embellishments, confusion with episodes of other periods, inversions).

When reconstructing history by confronting data from all available sources, the investigator searches through a network of clues and hints for the most plausible scenario. As he sails up the stream of time, however, texts become less frequent, their content of historical data lower, the data itself more blurred, and he ends up being unable, for lack of data, to propose a coherent and reasonably plausible scenario. Here and there a toponym, a more or less mythical character's name, or a very ancient particle of action subsist, but they cannot be connected to each other. I use the term extreme time depth for the collective memory of a given community, the approximate date beyond which any attempt to reconstruct history is

${ }^{10}$ A general term for this affliction all over Borneo is busung (see R. Blust, "Linguistic Evidence for Some Early Austronesian Taboos," American Anthropologist 83[1981]: 285-319).

11 As elsewhere in Southeast Asia, the tiger is linked with the taboos. In Borneo the Tiger is the avenger of transgressions, the agent of punishment, but he is at the same time the mystical healer of man's suffering (see Sellato, "Le mythe du Tigre").

12 However, the very fact that the Seputan at some point acquired the domestic pig and became acquainted with the ritual is relevant to the reconstruction of cultural interactions and Seputan cultural history. Besides, the names of the spirit-forebears probably refer to real Seputan leaders of forgotten times. 
doomed to failure. This date is then the limit for the articulated collective memory of the whole of the community. Of course, this memory is disseminated amongst the various informants of the community. We will see that this time depth differs from one ethnic group to the other, and how it differs.

\section{From History to Myth}

Historical and mythical elements are intimately intermingled in oral tradition. Mythical stories may carry some historical information. Where do we find, between historical narrative and myth, this dividing line we have called the extreme time depth?

Text number 3 is barren of historical information to be used for reconstructions; that is, it cannot be linked to Seputan history such as can be seized through genealogies. Nevertheless, this purification ritual has really been transmitted to the Seputan by another ethnic group (or one of its members). A minimal plot of action subsists. Some cultural hero was transformed into the Tiger. Here, he appears in a dream, whereas in Aoheng texts he is made of flesh in the shape of either tiger or man, always named Tiger, and he eats food raw. The groups of Borneo distinguish well between tiger and panther, and describe the former correctly although they have never seen one. Collective memory has probably preserved the remembrance of real encounters with tigers in very ancient times, and maybe not in Borneo. ${ }^{13}$

The transformation of a historical character into an animal through a historical narrative's evolution into a mythical story is a common thing, and it is further stimulated by the use of names of animals as common personal names. An Aoheng myth of West Kalimantan features a Seluang, a stranger coming from downstream the Kapuas River, who waged war on two brothers. In the course of the war, he eventually transformed himself and his whole army into small fish, the seluang fish, ${ }^{14}$ but the brothers' grandfather, a magician, caught them all in his blowpipe and blew them away into the sky. It can be assumed that, one day, some chief by the name of Seluang came to wage war on some proto-Aoheng group, but no conclusion can be reached regarding this war's outcome. The East Kalimantan Aoheng, who do not (or no longer) know this myth, keep on mentioning the "war of the seluang fish" and wondering how those tiny fish might well have attacked men.

A similar transposition is found in the "war of the ants" that the Aoheng relate as follows: "A high river flood followed by a sudden subsidence had left huge quantities of dead fish on firm ground, and ants (nyevérang) invaded the area to eat the fish. They eventually assailed the Amüe [an ancient subgroup of the Aoheng], who abandoned their village and took refuge with the Acüe [another subgroup]. To obtain shelter and protection, they had to enter into vassalage." According to reconstructions based on settlement sequences, this episode dates back to slightly before 1800 . The whole story could have been taken literally had it not been for the Dutch traveler Nieuwenhuis' mention of an ancient tribe called Neberang that had lived in this area. ${ }^{15}$

13 See Lord Medway, Mammals of Borneo. Royal Asiatic Society (Malaysian Branch) Monograph no. 7 (1977), p. 139. Note that all Borneo languages distinguish lexically between tiger and panther, although there are no tigers in Borneo.

14 The small seluang fish may be Chola oxygastroides (Cyprinidaeae).

15 A. W. Nieuwenhuis, Quer Durch Borneo, 2 vols. (Leiden: Brill, 1904-1907): 1, 277; See also Sellato, Les nomades forestiers, pp. 295-301, 309-11, 416-18. 
Then, it might well be that those Ne-berang attacked the Amüe, forcing them to request protection from the Acuié. The homophony of the two names and the temptation for the Amüe to erase the memory of a terrible episode of their history leads me to believe that a whole scenario was elaborated by the Amüe around the word nyeverang ("ant") to explain their escape and the loss of their sovereignty. As in Text number 2, the investigator thinks he has a grasp on the real historical event, but doubts remain cast on his hypothesis because no other text is available to validate it, since the Aoheng themselves do not know (any more) who the Ne-berang were.

This story of the "war of the ants," which could be called historico-mythical, is an extreme case: it provides a real historical fact-the Amüe took refuge with their neighbors and became their vassals-which has been confirmed by other texts. But, as for the reason for this retreat-a war of the ants or a war of the Ne-berang-a decision cannot reasonably be reached between the tradition's version and the investigator's. In this particular example, we probably stand exactly at the extreme time depth of the Aoheng's articulate collective memory.

\section{Social Structure and Way of Life}

Before I attempt a parallel between way of life and collective memory, I will contemplate four ethnic groups as references and describe briefly their social-economic features, at least those seeming relevant to the scope of this study: an outline of the history of their way of life, some population figures, their economic features, and their social organization. The extreme time depth of coherent historical reconstruction will be provided, with some comments relevant to each group's specific features.

Three of these groups, studied in 1979-1981, are tiny, little-known ethnic entities, whose main feature is the partial reliance of their economy on several species of wild sago, mainly Eugeissona utilis (nango). The fourth group, introduced for comparison purposes, is a large one, having been practicing swidden rice farming for at least some 250 years.

\section{The Bukat}

The Bukat ${ }^{16}$ maintained their traditional, almost totally nomadic way of life until around 1925-1930. Their economy, based on wild sago, collecting, hunting and fishing, implied frequent traveling. The migration unit, the band, was the extended family or a group of two or three related families. It seems that, for subsistence reasons, group size was limited to around 30 individuals. Originating, they say, from the Upper Mendalam River (West Kalimantan), the Bukat bands nevertheless dispersed on long-ranging, more or less circular migrations through the headwaters of the Baleh (Sarawak) and the Mahakam (East Kalimantan). Territorial notions are in fact rather vague. Most Bukat bands lived in areas upstream from settled farming groups, trading with them and, eventually, helping them with agricultural tasks and establishing, in some cases, a temporary symbiotic system. Their notions of identity also seem hazy. Two facts must be stressed: the extreme spatial mobility of each economic unit (the band) and a leaning toward band fissioning and fusing in the course of migrations.

\footnotetext{
16 See a more elaborate reconstruction of the history of the Bukat in Sellato, Nomades et sédentarisation, pp. 35108.
} 
Around 1925, after a transitory period near the Aoheng of East Kalimantan, the Bukat built their first autonomous village. A similar process took place around 1930 for the Bukat of West Kalimantan. They do cultivate some rice nowadays, but they are said to be poor farmers, since they disappear regularly into the forest, abandoning their fields. They remain nomads at heart, do not much like the taste of rice, preferring that of sago, and they possibly spend as much as six months a year in the forest in small, scattered groups.

The leader was traditionally chosen for his/her qualities of wisdom and experience and was the one best able to take the band along the sago-clump and fruit grove itineraries, also taking advantage of wild boar herds' migrations and of the ripening of wild fruit. Nowadays, in their hamlets of little more than 100 souls, they display an egalitarian social organization, although it might be that, in some communities, the function of the leader has tended to become more hereditary under other ethnic groups' influence.

A reconstruction of Bukat history is easy for the period since their sedentarization. It is more difficult for the period 1880 to 1920 because of the high number of tiny bands, some of which have since disappeared as separate entities. For the period prior to 1880 , the historical data provided by Bukat oral tradition alone have become insufficient. ${ }^{17}$

\section{The Hovongan (or Punan Bungan)}

The Hovongan disavow the ethnonym Punan and state that they have always practiced agriculture. Indeed, their secondary forest extends over vast tracts of their territory. ${ }^{18}$ They live in three small hamlets ${ }^{19}$ of some 100 people each, but stress that once they were much more numerous. They display little social differentiation, with no aristocratic category, and their genealogies show a half-hereditary, half-elective type of leadership that subsisted until the Dutch administration intervened (early 20th century), introducing ranks and titles which have since become hereditary.

Although all Hovongan practice some agriculture, they spend an average of four months a year in the forest (between the firing of the fields and the sowing, and between the weeding and the harvest), living off wild sago, hunting, and fishing, scattered in family groupings similar to the Bukat bands. During these periods in the forest they always remain within their traditional territory-the Bungan River basin and the left tributaries of the uppermost Kapuas-and, often, within less than three days' walk from the village. Their mobility outside their territory is low, but their segmental mobility (extended families) within it is high. This territorial sedentarity contributes to making their feelings of ethnic identity stronger than the Bukat's. The whole middle Bungan river area (the heart of the Hovongan country) displays plenty of historical sites (sites of old settlements, caves, boul-

\footnotetext{
${ }^{17}$ However, using also a few written sources and the oral tradition of neighboring settled groups, some sense can be made of this poor data obtained from the Bukat's own oral tradition, allowing the investigator to propose a reasonably reliable historical reconstruction extending well back into the first half of the 19 th century (ibid., pp. 39-47).

${ }^{18}$ A. W. Nieuwenhuis (In Centraal Borneo, 2 vols. [Leiden: Brill, 1900], p. 189), visiting the Hovongan in the 1890s, noted that they were subsisting on a combination of cultivated rice and tubers and of wild sago. This was still true in 1980. I suggested that the Hovongan first got acquainted with farming in the second half of the 18th century ("Les nomades forestiers," pp. 299-300, 416) and with rice several decades later (ibid., pp. 319, 326; Nomades et sédentarisation, pp. 222, 253), but have remained, to this day, uninterested in making rice their staple food. Indeed, they are now earning much of their living from the gold they pan in their streams.

19 There are now (1990) five hamlets, as two of the original three have each split in two, the outgoing sections moving downstream to the mouth of their respective tributaries.
} 
ders, and other landmarks) and the rooting of the oral tradition in the landscape strengthens the collective memory.

The history of the Hovongan can be reconstructed from their own tradition with not much difficulty up to about $\mathbf{1 8 0 0}$. Names of leaders and settlements from that period remain coherently connected. For the Hovongan, as for the Seputan of East Kalimantan, the term Punan still applied to them by outsiders should be reconsidered. ${ }^{20}$

\section{The Aoheng (or Penihing)}

The Aoheng form a homogeneous ethnic group of about 2,000 people and their biggest village has some 600.21 For the Long-Apari subgroup, the most numerous and the most Aoheng of all five subgroups, history can be summarized in two periods. The pre-agricultural period saw a half dozen small, rival groups scattered on the tributaries of the uppermost Mahakam and living, the Aoheng say, in caves or on top of rocky spurs. They stress that they have always lived there, and it seems that they were hunter-gatherers with a relatively fixed settlement pattern (hamlet or cave). This situation deserves a special study; as it does not seem viable, except for very small groups similar in size to the Bukat band, on territories wide enough for their subsistence. Around 1800-1820, the Aoheng were "civilized"; that is, settled and controlled, if not really subjugated, by the downstream Busang and Kayan groups which taught them rice agriculture and lent them their social stratification and some of their religion. In these three fields the Aoheng, even today, show less rigidity and diligence than their mentors, and partially resort to wild sago for one or two months at the end of the farming cycle.

From the times prior to 1800 , we still have a few names and plots, but nothing really articulate enough to allow for a coherent reconstruction. For the second, agricultural period, history is recalled with precision through sung epics, genealogies, and the wars and alliances of boisterous dynasties.

\section{The Bahau, Busang, and Kayan}

This important ethnic complex consists of the Bahau of the Middle Mahakam, and the Busang, Uma' Suling, Long-Gelat, and Kayan of the Upper Mahakam. ${ }^{22}$ These groups have arrived there in successive waves since the mid-18th century, as their tradition has it, from the northern plateaus of Apo Kayan where they were already practicing swidden agriculture. The Kayan have been thoroughly studied in Sarawak, where they are also present, and also in West Kalimantan.23 We have only to stress here that these societies are rigidly stratified in named classes and that leadership is strictly hereditary.

\footnotetext{
${ }^{20}$ These groups belong to the same linguistic grouping (see S.A. Wurm \& S. Hattori, eds., Language Atlas of the Pacific Area: Part II: Japan Area, Philippines and Taiwan, Mainland and Insular Southeast Asia [Canberra: The Australian Academy of the Humanities/Tokyo: The Japan Academy, 1983]). New data led me to reconsider an earlier statement concerning the date of sedentarization of the Seputan and to push it back to the very early 19th century at the latest for the Upper Kasau subgroup of the Seputan.

21 The Aoheng number now about 2,500. The distribution and population figures of the villages have been much altered, since the Aoheng have recently been subject to government-sponsored Resetelmen (Resettlement).

22 On history of in-migration to the Upper Mahakam area, see a brief outline in my 1980 paper and a more substantial description in my dissertation ("Les nomades forestiers," Pp. 301-307, 316-20, 417).

23 On the Kayan, see J. Rousseau, "The Social Organization of the Baluy Kayan" (Ph.D. dissertation, Cambridge University, 1974), idem., "Kayan Stratification," Man 14 (1979): 215-36; idem., Central Borneo-Ethnic Identity and
} 
In their oral tradition, genealogies extend over about one dozen generations, and precise detail has been preserved of the migrations from Apo Kayan. Their oral literature is rich in historical epics seemingly referring to events as ancient as the first half of the 18th century.

\section{Collective Memory}

Collective memory is an abstract concept, and the ways it proceeds, are not easy to analyze. ${ }^{24}$ We have seen above several processes of alteration of the historical narrative. How are, in Borneo, oral tradition-and particularly historical tradition-preserved and transmitted? Relevant socio-economic factors will be reviewed. Then, the question of Bornean peoples' notion of time will be considered.

\section{Preservation and Transmission of the Historical Tradition}

Individual factors first intervene. Who is the narrator? There are good narrators, and others who do not have the necessary qualities: some do not have a good memory; others do not socialize enough; others again do not have a good voice or a musical ear. A good narrator, such as it has been described to me by a dedicated listener, has lived in the house or in the surroundings of a famous deceased narrator, has felt like listening many times to the same story and learning it, is fortunate in having a good memory, and has a good and strong voice which is a plus for sung epics. As Jacques Dournes ${ }^{25}$ describes it, in mainland Southeast Asia: "A narrator recites, at night; in the audience, a youngster listens, dozes off at times, but the words keep on being recorded in him to the point that, after several auditions, he can reproduce himself the original text."

Familial and neighborhood factors are also relevant. Oral transmission, more often than not, occurs within the family, from grandfather to grandchildren, concerning some forebear or other, and their deeds. Epics, more appreciated and thus gathering a larger audience, reach the singer's wider surroundings.

The social factors are certainly the most important. It has been observed that in groups with a strong social stratification, it is the aristocratic class that is the recipient and guardian of the historical tradition and of the oral tradition in general. There are several reasons for this. One is that tradition is often ritual, and the important ritual functions are ascribed to members of the nobility. Furthermore, for a given ethnic group, history is equated with the history of the reigning family or dynasty. As Ida Nicolaisen 26 notes: "Historical and mythical traditions ... [are] closely connected to the ruling aristocrats." Then, transmission will preferably take place in these genealogical lines. It should also be stressed that, thanks to the corvée system, the high nobility families live in a relative idleness that allows them to devote much of their time to the arts and letters.

In highly structured societies (states or societies with incipient state formation), like the kingdoms of western Africa, the rulers devolve responsibility for preservation and transmission of the historical tradition to a special category of professional narrators (the griots),

Social Life in a Stratified Society (Oxford: Clarendon Press, 1990); on their oral literature, see S. Long Lii' and A. J. Ding Ngo, Syair Lawe', Bagian Pendahuluan (Yogyakarta: Gaja Mada University Press, 1984).

24 See M. Halbwachs, Les cadres sociaux de la mémoire (1925: Paris/The Hague: Mouton, 1976).

25 Forêt, Femme, Folie (Paris: Aubier-Montaigne, 1978), p. 196.

26 "Form and Function of Punan Bah Ethno-historical Tradition," Sarawak Museum Journal 24, 45 (1976): 65. 
whose function is equivalent to that of the official chroniclers at the kings' courts in literate societies.

Finally, modern factors in the current way of life of the ethnic groups under scrutiny must be taken into account. These are detrimental to the preservation of the corpus of oral tradition and, clearly, the young people are no longer motivated to learn it. Although they like to listen to an epic once in a while, they are not always able any more to grasp the esoteric, metaphoric tongue. The use of the tape-recorder might well trigger renewed interest in oral literature. Few people, however, are interested in their group's or village's history, as a heroic or grand past is not any more an emotionally relevant element for most of today's populations, living in the present and facing its daily challenges. History is of little concern to the bulk of the people, mainly because it is not really their history but rather that of their princes, who cling desperately to history to try and maintain their privileges. With social structures largely shattered by the modern world, people tend to look for individual solutions for the future (emigration, trade activities) at the expense of the village's future.

\section{Socio-economic Factors}

\section{Collective Memory and Population}

The number of individuals forming the community-village or ethnic group-is the most immediately relevant factor in the process of memorization and transmission of oral tradition. The more numerous the community, the more likely it is that individuals with qualities appropriate to a narrator are found. What probability is there of finding a good narrator in a band of thirty people? What opportunity would such a narrator, if any, have to find a gifted novice?

On the other hand, although it cannot be assumed that a small community has no history, it can be postulated that its history is less rich in salient episodes-wars, great expeditions, alliances-than that of a large ethnic group. The latter, besides providing a wide pool of good narrators and a guarantee for successors, offers abundant historical material, since its leaders strived for glory and fame.

\section{Collective Memory and Social Structure}

We said that in groups with a strong social stratification, a relative idleness allowed the nobility to keep oral tradition alive. In these groups, there is no differentiation into professional categories, and the narrators are amateurs (thus distinct from the griots), who practice their art in their leisure time (or in specific ritual contexts). It is then enough that such leisure time exists.

In these societies, keeping the oral tradition alive is compulsory. As Nicolaisen ${ }^{27}$ puts it: "The myth of origin and ethnohistorical tradition are of vital importance for maintenance of identity." The bond of a people to their reigning dynasty, and thus their feeling of ethnic identity, resides in the pride they have in the glorious episodes of their past; that is, the history of their royalty. The princes of the past needed, for their own sake, to maintain this pride, even if they had to induce alterations in the narratives in order, for example, to turn a trouncing into a victory. The nobility of today need badly to keep oral tradition alive and to resort to their forefathers' glory to maintain their hold on their commoners who, in the last decades, have strived to emancipate themselves from their social bond, refusing ritual

27 Ibid., p. 90. 
corvées, questioning their leaders' decisions, and simply emigrating. The commoners of the past, working full time to ensure their subsistence, not to mention corvées imposed by the nobility, were not much concerned with learning and transmitting the tradition, restricting themselves to suffering under it. The commoners of today are just not interested in it.

In a small nomadic community, the picture is different. All individuals are equally busy full time with economic activities that are primordial to the group's survival. A griot would be an economically unproductive person, something acceptable for a disabled elder but not for a young person, the potential recipient of the oral tradition from the elderly one. Such a community simply could not afford (and indeed, would refuse) to feed idlers.

\section{Notions of Time}

Here again is a delicate point. As seen above, the coherent collective memory of a large sedentary group covers at least ten generations (reaching 25 in some documented cases), whereas that of a small nomadic community hardly extends over one century, and sometimes little over a half-century. For example, the Punan Busang cannot remember their history prior to $1900-1920,28$ and the Punan Lusong seem not to recall anything of times prior to $1870 .^{29}$ This has been confirmed by several other studies on the Punan (or Penan) groups of Sarawak. ${ }^{30}$

This is certainly due pro parte to the factors mentioned above. But we can go further. "The Punans appear to have very little in the way of traditions, and they do not usually have heroes, ... , or in any way keep alive the past." 31 The same author notes elsewhere:32 "A Pennan has no sense of time and very little sense of numbers." To say that the nomads have no sense of time is certainly somewhat excessive. It is true, however, that Borneo does not have clear-cut seasons, with the monsoons hardly perceptible. True also that the ripening of wild fruit is erratic, like the wild boars' migrations. Possible time markers along the year for the Punan are the episodic contacts they have with the farming peoples, but these markers are hardly relevant to nomads to whom the agricultural cycle is meaningless.

When recent events are concerned (say, between five years and one generation ago), the Punan are no less competent than the farmers. When I returned among the Busang and Aoheng farmers in 1979, no one was able to recall with precision what year my earlier visit was (1975). If they had taken the pains to compute their successive swiddens, they would have come up with an accurate answer. It is not a new idea to say that the Dayak are not very interested in computing time.

It is in the notion of historic time, the time that is measured in the number of generations, that nomads and farmers differ. This notion exists only when it is supported by a historical tradition which in turn exists only if the society needs it to maintain itself as it stands, to maintain its stratification and its identity. We can then posit the following causal sequence: Existence of a social stratification $\rightarrow$ need to maintain it $\rightarrow$ need for a historical tradition $\rightarrow$ need for a notion of historic time. As it appears that, in Borneo, the correlation

28 D. B. Ellis, "A Study of the Punan Busang," Sarawak Museum Journal 20, 40-41 (1972): 237.

29 Jayl Langub, "Distribution of Penan and Punan in the Belaga District," Bormeo Research Bulletin 7, 2 (1975): 46; I.A.N. Urquhart, "Some Notes on Jungle Penans in Kapit District," Sarawak Museum Journal 5 (1951): 498.

${ }^{30}$ See references in Sellato, Nomades et sédentarisation, p. 249.

31 Urquhart, "Some Notes," p. 497.

32 I. A. N. Urquhart, "Nomadic Punans and Pennans," in The Peoples of Sarawak, ed. T. Harrisson (Kuching: Sarawak Museum, 1959), p. 79 
between nomadic hunting-gathering societies and the absence of social stratification (see Note 1) is established for most known cases, it seems consistent that these societies lack a notion of historic time.

So these nomads do remember their recent past leaders but do not care to preserve the memory of a reputed leader in order to maintain or legitimize a social stratification they do not have. Why would they need to learn long genealogies? They have no titles, no functions, even no lands of which they could claim ownership. If "(T)he aristocratic genealogy serves as measurement of time," 33 we can just as well state that this measurement of time is, within historical tradition, a tool for the aristocrats to maintain their society as it stands, and maintain themselves where their genealogies have placed them. A society of nomadic huntergatherers, having traditionally no nobility, does not feel the need to preserve a historical tradition.

\section{Ethnic Identity}

A notion of ethnic identity rests on other notions people have of their linguistic, racial, cultural, or territorial affiliation or ascription. Local use of ethnic or other categories or typologies and the problem of ethnonyms tend to blur the picture. The Busang consider themselves ethnically distinct from their Mahakam Kayan neighbors and identify with the Kayan of Apo Kayan, Sarawak, or West Kalimantan, since they speak the true Kayan language originating in Apo Kayan, although they are probably not true ethnic Kayan. Conversely the Mahakam Kayan, although they are true ethnic Kayan from Apo Kayan, speak a language derived from that of their numerous Ot Danum slaves. The Cihan (Tiong Ohang) subgroup of the Aoheng see themselves as primarily Aoheng, because they are ethnically and linguistically Aoheng, but they are also proud to consider themselves Kayan, because their leaders are descended from Kayan nobility and their customs have been Kayanized. The Seputan are proud of practicing the sophisticated adat of the Busang and despise the Hovongan, who are really their close ethnic and linguistic kin.

The feeling of ethnic identity likely rests on a varying consideration of these linguistic, geographic, and cultural factors. How is it among the nomads? They move around a lot, often migrating over long distances, and their territorial notions are hazy. Besides, they speak several languages fluently, their own being subject to heavy linguistic influences from neighboring farmers, and they do not seem to have much of a feeling of linguistic identity. Their customs and taboos have been found generally to be either poorly elaborated or borrowed (most often from the large neighboring agricultural groups). This is a common feature among Borneo's hunting-gathering groups. These cultural borrowings do not preclude the existence of another, underlying cultural layer, which is their own but is not easily detectable. ${ }^{34}$

Commonly, hunting-gathering groups have no autonym, and when they do have one, it often is of the "we, human beings" type, 35 which refers more to a rainforest zoological taxonomy than to an ethnic feeling. The nomads of Borneo generally comply to this rule. They have, however, numerous exonyms, referring to river or mountain names and changing in the course of their migrations and according to the various agricultural groups with whom

\footnotetext{
${ }^{33}$ Nicolaisen, "Form and Function," p. 65.

34 This comment was from A. Testart (1980 personal communication; see also idem, "Pour une typologie des chasseurs-cueilleurs," Anthropologie et Sociétés 5, 2 (1981): 177-221. I have developed this idea further for Borneo in Nomades et sédentarisation (pp. 251-55) and particularly in a forthcoming paper.

35 Testart, personal communication.
} 
they are in contact. In such contacts, the nomad defines himself as "Punan," followed by a toponym, in order to position himself in the farmers' typology. He makes no effort to impose his autonym, if any, and does not care about the names applied to him. The name Bukat itself (autonym: BukØt) comes from the ancient name of the Mendalam River (Upper Kapuas basin) and now applies only to communities remaining in this area and those having left recently.

These nomadic groups, we have said, split, move, and change names. Each band goes through its respective history, in various regions, and undergoes influences from various farming groups. In a Borneo which offers "a picture of populations continually becoming something else," 36 each band progressively becomes something other than its cousin band. How, then, can several small bands, having culturally and linguistically evolved along different lines and residing far away from one another, have a feeling of common ethnic identity? How, in a band of thirty persons, can a feeling of ethnicity exist, which might rather be called a familial feeling? Without a strong historical tradition, giving each of these bands the pride of a famous common forebear, a name, or an original territory, ethnic identity seems unable to develop (see Note 1).

\section{Collective Memory and Way of Life}

Finally, it appears that it is the way of life that conditions the more or less extensive capacity for collective memory. If we dig further into this, we might say that the way of life determines the need for collective memory and conditions the ability to fulfill this need, and the result is the capacity for collective memory in a given community, which can be measured by its extreme time depth.

Among the groups considered in the course of this study, two polar extremes can be described briefly. The small nomadic band, because of its limited population and, mostly, of its egalitarianism-two inferences from its type of economy-does not need to preserve its historical tradition over long periods. Conversely, a large settled group produces narrators from an idle aristocratic class which inherited a rich oral tradition that it needs to keep alive in order to maintain the group's social structure and identity. To the practice of swidden agriculture and the sedentary habitat is attached a vast set of rites-farming rites, of course, but also purification and funerary rites-that also provide matters for oral tradition and that the nomads appear to ignore.

Between these two poles, the Aoheng and Hovongan constitute mixed types, in two different ways. The Aoheng form a mixed type in a time frame: a period where they lived scattered, probably as hunter-gatherers, is followed by a period of sedentary agricultural economy. It is the same sequence as for the Bukat and Punan, but the transition of the two periods occurred much earlier-around 1820, instead of 1925 for the Bukat and 1960-1970 for the Sarawak Punan. From the second period, we still have a historical tradition as rich as that of the Kayan and Busang, the marginal resort to wild sago having apparently little bearing. From the first period, very little remains.

The Hovongan form a mixed type in a space frame: they have lived and still live a double life. Their need for wild sago leads them to spend an important part of the year as small isolated family groups, with an economy very similar to that of the Bukat before 1925 and to that of some Sarawak Punan to this day. This is particularly interesting. The Hovongan live in two distinct environments, the village and the forest, and in two distinct

${ }^{36}$ T. Babcock, "Indigenous Ethnicity in Sarawak," Sarawak Museum Journal 22, 43 (1974): 196. 
socio-economic contexts, one of the sedentary type-involving a village life, a need for social structure and ethnic identity, problems of influence, leadership, inheritance, and collective decisions and rites, and therefore a need for oral tradition-and the other of the nomadic type, canceling these very same needs. As a result of this double life, as we saw, social organization is hazy and ethnic identity is weak. Here the recourse to wild sago is a factor inhibiting village life, thus limiting the capacity for collective memory, which is similar to that of the Aoheng but inferior to that of the large sedentary groups.

In the studies on the Punan, there is an exception, that of the Punan Aput, whose historical tradition goes back in time to the period when the Kayan were still in Apo Kayan;37 that is, the second half of the 18th century. Several authors have raised the hypothesis that the nomadic groups of Borneo had been agriculturalists in the past and came to hunting-gathering through a devolutionary process. ${ }^{38}$ A study of the extreme time depth, carried out along with one on social organization, might prove helpful in discriminating amongst nomadic groups.

From the above, it appears that we can reasonably, in the context of Borneo, establish the following implications. The existence of social stratification implies the need to maintain it, thus the need for a historical tradition. Practically, the recourse to the historical tradition contributes to maintaining the stratification, which requires the preservation of the historical tradition; thus the greater time depth of collective memory. Conversely, a nomadic hunting-gathering economy with the band as the economic unit determines the absence of social stratification. Then there is no need for a historical tradition nor for a maintenance of the collective memory, hence a shallower time depth. Secondarily, the absence of a historical tradition seems linked to a hazy notion of ethnic identity and to the absence of a notion of historic time.

Table 1 summarizes the major factors of social structure, economy, and way of life for the four ethnic groups under study, and signals without nuance their positive $(+)$ or negative (-) influence on these groups' capacity for collective memory and the resulting extreme time depth.

37 Tuton Kaboy, "The Punan A put," Sarawak Museum Journal 22, 43 (1974): 287.

38 E.g., Martinoir (cited in J. Rousseau, "Ethnic Identity and Social Relations in Central Borneo," in Pluralism in Malaysia, Myth and Reality, ed. J. A. Nagata [Leiden: Brill, 1975]: 37); C. L. Hoffman, 'The 'Wild Punan' of Borneo: A Matter of Economics," in The Real and Imagined Role of Culture in Development: Case Studies from Indonesia, ed. Michael Dove (Honolulu: University of Hawaii Press, 1988); S. Seitz, "Die Penan in Sarawak und Brunei: Ihre Kultur-historische Einordnung und Gegenwärtige Sltuation," Paideuma 27 (1981): 275-311. I have dealt at length with this question of devolution of farming groups into nomadic groups in several publications ("The Nomads of Borneo: Hoffman and 'Devolution'," Borneo Research Bulletin 20, 2 [1988]: 106-20; Nomades et sédentarisation, pp. 153-55, 257-62; and "The Punan Question"), and concluded that there was no serious evidence to support the devolutionist theory. In any case, I stressed the total irrelevance of a polar opposition, often found in the literature, between hunting-gathering and paddy-farming economies, and the existence of a continuum of stable mixed subsistence economic systems relying on a combination of wild sago, cultivated tubers, and cultivated rice (Nomades et sédentarisation, pp. 216-31). 
Table 1. Factors Influencing Collective Memory

\begin{tabular}{|c|c|c|c|c|c|}
\hline Group & & Bukat & Hovongan & Aoheng & Busang \\
\hline \multirow{2}{*}{$\begin{array}{l}\text { Social } \\
\text { Factors }\end{array}$} & Leadership & elected (-) & mixed type & $\begin{array}{c}\text { before } 1820: \text { ? } \\
\text { aft. 1820: heredit.(+) }\end{array}$ & $\begin{array}{c}\text { hereditary } \\
(+)\end{array}$ \\
\hline & $\begin{array}{l}\text { Social } \\
\text { structure }\end{array}$ & egalitarian & $\begin{array}{l}\text { vague } \\
(-)\end{array}$ & $\begin{array}{l}\text { after } 1820(+) \\
\text { rather rigid }\end{array}$ & $\begin{array}{l}\text { very rigid } \\
(+)\end{array}$ \\
\hline \multirow{2}{*}{$\begin{array}{l}\text { Economic } \\
\text { Factors }\end{array}$} & $\begin{array}{l}\text { Economic } \\
\text { unit }\end{array}$ & $\begin{array}{l}\text { nomadic unit } \\
30 \text { persons (-) }\end{array}$ & $\begin{array}{ll}\text { village } & \text { forest } \\
100 \mathrm{p} . & 30 \mathrm{p} .\end{array}$ & $\begin{array}{c}\text { village }(t) \\
200-600 \text { pers. }\end{array}$ & $\begin{array}{c}\text { village (+) } \\
200-1,000 \mathrm{p} .\end{array}$ \\
\hline & $\begin{array}{l}\text { Need for } \\
\text { wild sago }\end{array}$ & $\begin{array}{l}\text { bef. } 1925: 12 \mathrm{mo}(-) \\
\text { today: } 6 \mathrm{mo} \text { ? }\end{array}$ & $\underset{(+)}{8 \mathrm{mo}} \quad 4 \mathrm{mo}$ & $\begin{array}{l}\text { bef. } 1820 \text { ?: } 12 \mathrm{mo}(-) \\
\text { today: } 1 \mathrm{mo}(+)\end{array}$ & $\begin{array}{l}\text { nil } \\
(+)\end{array}$ \\
\hline \multirow{3}{*}{$\begin{array}{l}\text { Way of } \\
\text { Life } \\
\text { (Economic } \\
\text { Mobility) }\end{array}$} & $\begin{array}{l}\text { Notion of } \\
\text { territory }\end{array}$ & very weak (-) & strong (t) & strong (t) & strong (+) \\
\hline & $\begin{array}{l}\text { Mobility out } \\
\text { of territory }\end{array}$ & strong (-) & weak (t) & weak $(+)$ & $\begin{array}{c}\text { very weak } \\
(+)\end{array}$ \\
\hline & $\begin{array}{l}\text { Mobility } \\
\text { in territory }\end{array}$ & strong (t) & strong (+) & weak (t) & $\begin{array}{c}\text { very weak } \\
(-?)\end{array}$ \\
\hline \multirow{3}{*}{$\begin{array}{l}\text { Collective } \\
\text { Memory }\end{array}$} & & $1870-1875$ & \multirow{2}{*}{1800} & 1800 & \multirow{2}{*}{ before 1750} \\
\hline & time depth & $\begin{array}{lr}\text { nomadic } & \text { settled } \\
1870-1925 & \text { aft. } 1925\end{array}$ & & $\begin{array}{lr}\text { nomadic } & \text { settled } \\
1800-20 & \text { aft. } 1820\end{array}$ & \\
\hline & $\begin{array}{l}\text { Known } \\
\text { Generations }\end{array}$ & 5 or 6 & 9 & 8 & 11 or 12 \\
\hline
\end{tabular}

